И.В. Шульга*

\title{
ЮРИДИЧЕСКАЯ ПРИРОДА ПРАВОВЫХ ПОЗИЦИЙ ВЕРХОВНОГО СУДА РФ
}

Аннотация: объектом исследования являются правовые позиции как особый правовой френомен в российской правовой системе. В предмет исследования входят правовые позиции Верховного Суда Российской Федерации как самостоятельная разновидность судебных правовых позиций. Изучение осуществляется исходя из представления о судебных правовых позициях как мнения правоприменителя, выраженного в актах правоприменения. В связи с этим правовые позиции Верховного Суда РФ рассматриваются в качестве мнения высшей судебной инстанции по вопросам применения норм права, которое отражено в судебных постановлениях по конкретным делам и разъяснениях судебной практики. Судебные правовые позиций выделяются по типу правоприменения. Правовые позиции Верховного Суда РФ относятся к их разновидности, что является методологической основой дальнейшего исследования. Формирование позиций Верховного Суда РФ происходит в процессе индивидуального судебного регулирования спорных правоотношений. $B$ связи $C$ этим в содержание правовых позиций включаются интерпретационные положения, результаты преодоления коллизий и пробелов в праве, применения принципов права. В тексте судебных постановлений правовые позичии Верховного Суда РФ обеспечивают переход от абстрактных норм права к обстоятельствам конкретного спора. По своей природе правовые позиции Верховного Суда РФ имеют не нормативный, а интерпретационный характер, что следует учитывать при их употреблении в судебных решениях. В сравнении с нормами права правовые позиции Верховного Суда РФ служат дополнительным обоснованием выводов суда и не могут подменять нормативных предписаний.

Ключевые слова: Суд общей юрисдикции, Норма права, Толкование, Индивидуальное судебное регулирование, правовые позиции суда, Верховный Суд РФ, Судебное правоприменение, Судебное постановление, Мотивировочная часть решения, Позиция Верховного Суда.

DOI: 10.7256/1994-1471.2014.2.10342

$\mathrm{B}$ первые термин «правовая позиция суда» получил нормативное закрепление в статье 73 Федерального Конституционного закона «О Конституционном Суде Российской Федерации» ${ }^{1}$. В связи с деятельностью Конституционного Суда РФ, а в последующем иных высших судов Российской Федерации правовые позиции стали объектом пристального внимания и вызвали активную научную дискуссию 2 .

\footnotetext{
1 Федеральный Конституционный закон от 21 июля 1994 г. № 1-ФКЗ «О Конституционном Суде Российской Федерации» // Собрание законодательства РФ. 1994. № 13. Ст. 1447; 2001. № 7. Ст. 605; 2001. № 51. Ст. 4842; 2004. № 24. Ст. 2334; 2005. № 15. Ст. 1273; 2007. № 7. 829; 2009. № 23. 2754; 2010. № 45. Ст. 5742; 2011. № 1. Ст. 1; 2012. № 53. Ст. 7572; 2013. № 14. Ст. 1637.
}

2 Марченко М. Н. Судебное правотворчество и судейское право. М., 2008. 512 с.; Кряжкова О. Н. Правовые позиции Конституционного Суда РФ: теоретические основы и практика реализации судами России. М., 2006. 152 с.; Ершов В. В. Правовая природа правовых
В юридической литературе сложилось мнение о том, что правовые позиции могут формироваться всеми судами в процессе правоприменения. Практику Европейского Суда по правам человека в аспекте его правовых пози-

позиций суда // Российское правосудие. 2013. № 6. С. 37 - 47; Власенко Н. А., Гринева А. В. Судебные правовые позиции (основы теории). М., 2009. 168 с. ; Лазарев Л. В. Правовые позиции Конституционного Суда РФ. М., 2008. 688 с.; Гусева Т. А. Значение судебных актов Конституционного суда РФ // Ваш налоговый адвокат. 2008. № 5. С. 18-25; Барановский К. В., Безруков А. В., Калугин А. Г. Влияние правовых позиций Конституционного Суда РФ на уголовно-процессуальное законодательство и практику // Журнал российского права. 2007. № 11. С. 56-68; Бурков А. Л. Акты правосудия как источники административного права: Автореф. дисс.... канд. юрид. наук. Екатеринбург, 2002. 19 с. ; Ножкина А. В. Система источников уголовно-процессуального права России: Дисс. ... канд. юрид. наук. М., 2003. 190 с.; Фархтдинов Я. В. Источники гражданского процессуального права Российской Федерации: Дисс. ... Д-ра юрид. наук. Екатеринбург. 2002. 375 с.

(C) Шульга Иван Владимирович

* Аспирант кафедры теории права и судебной власти Российской академии правосудия [Mr_Van@mail.ru]

675000, Россия, Амурская область, г. Благовещенск, ул. Шевченко, 6. 
ций изучают Н.В. Витрук ${ }^{3}$, Л.В. Туманова ${ }^{4}$, В.И. Анишина ${ }^{5}$ и другие авторы ${ }^{6}$ В.В. Ершов и Е.А. Ершова используют теоретические положения о правовых позициях Конституционного Суда Российской Федерации при рассмотрении позиций иных судебных органов, в том числе Европейского Суда по правам человека7. Как указано в п. 2, 3 и 4 Постановления Пленума Верховного Суда РФ от 27 июня 2013 года № 21 «0 применении судами общей юрисдикции Конвенции о защите прав человека и основных свобод от 4 ноября 1950 года и Протоколов к ней», правовые позиции Европейского Суда, изложенные в ставших окончательными постановлениях, учитываются при применении законодательства и международных договоров Российской Федерации ${ }^{8}$.

Правовые позиции выявляются и в деятельности арбитражных судов ${ }^{9}$. В рамках исследований затрагиваются проблемы приоритета правовых позиций вышестоящего суда по отношению к правовым позициям нижестоящих судов $^{10}$.

Обсуждение природы судебных правовых позиций приобрело особую остроту в связи с вопросом о возможности относить судебную

\footnotetext{
Витрук Н. В. О некоторых особенностях использования решений Европейского Суда по правам человека в практике Конституционного Суда РФ и иных судов. Антология научной мысли: К 10-летию Российской академии правосудия: Сборник статей. М., 2008. С. 548-549.

4 Туманова Л. В. Проблемы обеспечения права на независимый и беспристрастный суд // Концепция развития судебной системы и системы добровольного и принудительного исполнения решений Конституционного Суда РФ, судов общей юрисдикции, арбитражных, третейских судов и Европейского Суда по правам человека: сб. науч. ст. / Отв. ред. Г. Д. Улетова. СПб., 2007. С. 28.
}

Основы судебной власти и правосудия в РФ: курс лекций / Под ред. В. И. Анишиной. М., 2008. С. 263.

6 Дихтяр А. И., Рогожин Н. А. Источники права и судебная практика // Юрист. 2003. № 1. С.2-7.

Ершов В. В., Ершова Е. А. О правовом статусе Конституционного Суда Российской Федерации // Российская юстиция. 2004. № 2. С. 25 ; Ершова Е. А. Юридическая природа правовых позиций Конституционного Суда //Российский судья. 2005. № 2. С. 14; Самостоятельность и независимость судебной власти в Российской Федерации / под ред. В. В. Ершова. М., 2006. С. 168.

8 Постановление Пленума Верховного Суда РФ «О применении судами общей юрисдикции Конвенции о защите прав человека и основных свобод от 4 ноября 1950 года и Протоколов к ней» от 27 июня 2013 г. № 21 // Российская газета. 2013. № 145. С. 7-8.

9 Красюков А. В. Правовые позиции Высшего Арбитражного Суда РФ и налоговое обязательство // Российское правосудие. 2011. № 9. С. 77-84; Власенко Л. В. Налоговые правовые позиции судов: теория и практика. M., 2011. 160 c.

10 Груздев В. В. Проблемы судебного толкования права в России // Российский судья. 2008. № 5. С. 38. практику к источникам российского права. Ряд ученых предложил рассматривать правовые позиции Конституционного Суда Российской Федерации, а также других высших судов Российской Федерации и Европейского Суда по правам человека в качестве самостоятельных источников права ${ }^{11}$.

Федеральным Конституционным законом от 3 ноября 2010 года № 7-ФКЗ ${ }^{12}$ названная выше статья 73 признана утратившей силу. В то же время статья 79 Федерального Конституционного закона «О Конституционном Суде Российской Федерации» дополнена частью 5, согласно которой позиция Конституционного Суда Российской Федерации относительно того, соответствует ли Конституции Российской Федерации смысл нормативного правового акта или его отдельного положения, выраженная в постановлении Конституционного Суда Российской Федерации, подлежит учету правоприменительными органами с момента вступления в силу соответствующего постановления. Данное изменение, по мнению проф. Н.В. Витрука, заключается в признании законодателем правомерности практики выявления Конституционным Судом конституционноправового смысла нормативного акта и определении юридических последствий такой практики ${ }^{13}$.

Таким образом, термин «правовая позиция суда» прочно вошел в теорию и практику юриспруденции. Законодательные изменения лишь подчеркивают значимость обозначаемого таким образом правового явления. Подобная ситуация складывается и в некоторых других странах на постсоветском пространстве, например, в Республике Украина ${ }^{14}$.

В юридической литературе выделение судебных правовых позиций в правопримени-

11 Зорькин В. Д. Прецедентный характер решений Конституционного Суда РФ // Журнал российского права. 2004. № 12. С. 7; Гаджиев Г. А. Правовые позиции Конституционного Суда РФ как новый источник российского гражданского права // Закон. 2006. № 11. С. 23.

12 Федеральный Конституционный закон от 3 ноября 2010 г. № 7-ФКЗ «О внесении изменений в Федеральный Конституционный закон «О Конституционном Суде Российской Федерации» // Собрание законодательства РФ. 2010. № 45. СТ. 5742.

13 Витрук Н. В. Новое в конституционном судопроизводстве (к вступлению в силу федерального конституционного закона от 3 ноября 2010 года) // Российское правосудие. 2011. № 3. С. 12.

14 Бочаров Д. А. О субъектах правых позиций и специфике их правосубъектности // Проблемы правосубъектности: современные интерпретации. Материалы международной науч.-практ. конференции 25 февраля 2011 года, г. Самара / Отв. ред. Т.Б. Замотаева и др. Самара, 2011. С. 115-121. 
тельной деятельности традиционно связывается с типом правоприменения ${ }^{15}$. Изначально судебные правовые позиции определяются как суждения суда (судебной инстанции) ${ }^{16}$ и представляют собой разновидность мнения правоприменителя. Правовая позиция суда рассматривается в качестве системного изложения суждений судебной инстанции или других субъектов по поводу судебного правоприменения $^{17}$, либо как мыслительный акт, выраженный в текстовом системном изложении суждений судебной инстанции о мотивах применения юридической нормы ${ }^{18}$. В основе судебной правовой позиции лежит идея, которая объединяет отдельные суждения в целостное решение спорной правовой ситуации. Таким образом, судебные правовые позиции следует понимать как связанные общей идеей единые системы суждений суда (судьи) относительно понимания и применения правовых норм, выраженные в постановлениях по конкретным делам и разъяснениях судебной практики.

Анализ правоприменительной практики свидетельствует о том, что судьи судов общей юрисдикции все чаще ориентируются в своих решениях на позицию высшего судебного органа. В недавнем прошлом ссылки на позицию Верховного Суда РФ в судебных постановлениях были редким исключением. В настоящее время ситуация изменилась принципиально. Например, подавляющее большинство «отказных» определений кассационной инстанции Амурского областного суда по гражданским делам обосновано положениями Постановления Пленума Верховного Суда Российской Федерации от 11 декабря 2012 года № 29 «0 применении судами норм гражданского процессуального законодательства, регулирующих производство в суде кассационной инстанции» ${ }^{19}$. Подобный подход разделяется Верховным Судом РФ, что находит отражение в мотивировочной части принимаемых им постановлений по конкретным делам ${ }^{20}$. 0 нали-

15 Власенко Н. А., Гринева А. В. Указ. соч. С. 37.

16 Власенко Н. А., Гринева А. В. Указ. соч. С. 46.

17 Власенко Н. А. «Тревожные» вопросы по поводу судебных правовых позиций // Новая юстиция. 2008. № 1. C. 24.

18 Гринева А. В. Судебные правовые позиции: вопросы теории: Автореф. дисс... канд. юридич. наук. М., 2008. С. 8.

19 Постановление Пленума Верховного Суда РФ «О применении судами норм гражданского процессуального законодательства, регулирующих производство в суде кассационной инстанции» от 11 декабря 2012 г. № 29 // Бюллетень Верховного Суда РФ. 2013. № 2. С. 6 - 11.

20 Определение Верховного Суда РФ от 13.06.2013 № АПЛ13-227 //СПС «КонсультантПлюс»; Определение Верховного Суда РФ от 28.08.2013 № 15-АПГ13-4 // чии ранее сформированной позиции высшего судебного органа указывается в разъяснениях судебной практики ${ }^{21}$. Множество подобных примеров приводит к выводу о формировании в судебной практике тенденции к увеличению количества ссылок на позиции Верховного Суда Российской Федерации в тексте судебных постановлений.

Как следствие, вопрос о юридической природе правовых позиций Верховного Суда РФ приобретает особое значение. Ключевым для его решения является теоретическое представление о принадлежности этого феномена к разновидности судебных правовых позиций в сфере правоприменения.

Акт судебного правоприменения должен разрабатываться и приниматься на основании и в соответствии с нормами действующего права. В теории права единство интеллектуально-волевой деятельности по уяснению и разъяснению смысла норм права в целях их реализации принято рассматривать как толкование ${ }^{22}$. В ходе толкования формируется определенное новое знание о содержании нормы права. Новизна таких знаний состоит в том, что при интерпретации достигаются более конкретные и детальные знания о содержании абстрактной нормы права ${ }^{23}$.

Правовые позиции Верховного Суда РФ в силу своей правоприменительной природы опираются на действующее право. Входящие в их состав суждения являются результатом мыслительного процесса выбора и осмысления норм материального и процессуального права. Толкование необходимо для применения правовой нормы к обстоятельствам каждого конкретного рассматриваемого судом случая.

СПС «КонсультантПлюс»; Постановление Верховного Суда РФ от 05.03.2013 N 8-АД13-1 //СПС «КонсультантПлюс»; Кассационное определение Верховного Суда РФ от 06.03.2013 № 55-О13-1 //СПС «КонсультантПлюс».

21 Обзор практики разрешения судами споров, связанных с воспитанием детей, утв. Президиумом Верховного Суда РФ 20 июля 2011 года // Бюллетень Верховного Суда РФ. 2012. № 7. С. 33 ; Обзор законодательства и судебной практики Верховного Суда Российской Федерации за второй квартал 2006 года // Бюллетень Верховного Суда РФ. 2007. № 1. С. 23.

22 Алексеев С. С. Право: азбука - теория - философия: Опыт комплексного исследования. М., 1999. С. 129; Аверин А. В. Правоприменительная деятельность суда и формирование научно-правового сознания судей. С. 179 ; Смирнов А. В., Манукян А. Г. Толкование норм права: учебно-практич. пособие. М., 2008. С. 6-11; Нерсесянц В. С. Теория государства и права. М., 2001. С. 223; Теория права и государства / под ред. В. В. Лазарева. М., 2002. С. 290.

23 Черданцев А. Ф. Толкование советского права. М., 1979. С. 29-30. 
Уяснение смысла правовой нормы с использованием приемов толкования служит одним из важных мыслительных процессов формирования судебных правовых позиций. Результат толкования в форме правоинтерпретационных положений составляет логико-правовую основу содержания правовых позиций Верховного Суда РФ. Единство процессов уяснения и разъяснения в ходе толкования правовых норм соответствует природе судебной правовой позиции, выступающей внутренним основанием конкретного судебного решения, его мотивационной базой.

Помимо правоинтерпретационных положений, правовые позиции Верховного Суда РФ включают в себя и другие элементы. К их числу исходя из выделяемых в юридической литературе видов индивидуального судебного регулирования относятся результаты преодоления коллизий в праве, толкования принципов права, применения факультативных, альтернативных, относительно определенных, диспозитивных норм права, преодоления пробелов в праве ${ }^{24}$.

Действительно, содержание судебной правовой позиции в формально-юридическом аспекте не исчерпывается результатами толкования, поскольку оно не применимо в случае обнаружения пробелов в праве или законе ${ }^{25}$. Неполнота, неясность и противоречивость закона не освобождают суд от вынесения решения по делу, так как отказ от разрешения дела по существу по данному основанию трактуется как отказ в правосудии ${ }^{26}$, что недопустимо в условиях правового государства. Среди иных приемов формирования правовых позиций высшего судебного органа можно назвать применение принципов права, которые, по справедливому признанию ученых, могут и должны служить правовым основанием решений судов, быть базой их правовых позиций, но не отождествляются с ней. Особую роль в формировании позиций Верховного Суда РФ, прежде всего по конкретным делам, играет судебное усмотрение. В содержание правовой позиции

\footnotetext{
24 Ершов В. В. Правовая природа правовых позиций суда // Российское правосудие. 2013. № 6. С. 44.

25 Васьковский Е. В. Цивилистическая методология. Учение о толковании и применении гражданских законов. М. 2002. С. 278-279, 361; Цихоцкий А. В. Аналогия права в механизме судебного правоприменения // Концепция развития судебной системы и системы добровольного и принудительного исполнения решений Конституционного Суда РФ, судов общей юрисдикции арбитражных, третейских судов и Европейского Суда по правам человека: Сб. науч. ст. / отв. ред. Г. Д. Улетова. СПб., 2007. С. 231.

26 Спектор Е. И. Судебный прецедент как источник права // Журнал российского права. 2003. № 5. С. 86.
}

в качестве неотъемлемой части включаются результаты осуществления судом полномочия выбирать из нескольких правомерных вариантов разрешения дела ${ }^{27}$.

Следовательно, по своей природе правовые позиции Верховного Суда РФ в сфере правоприменения являются производными от норм действующего права и представляют собой результат толкования правовых норм, использования аналогии закона и права, применения общих принципов права судами, а также механизмов судейского усмотрения в процессе индивидуального судебного регулирования общественных отношений. Можно сделать вывод о том, что правовая позиция Верховного Суда РФ опосредует собой переход от абстрактной нормы права к обстоятельствам конкретного рассматриваемого судом случая в процессе индивидуального судебного регулирования. В этом проявляется трансформативная функция, присущая правовым позициям судов ${ }^{28}$. Суждения в составе позиции Суда выводятся из предписаний действующего права и логически объединены общей целью.

Таким образом, в формально-юридическом смысле, в условиях правовой системы Российской Федерации судебные правовые позиции Верховного Суда Российской Федерации имеют не нормативный, а интерпретационный, правоконкретизирующий характер. В этом отношении справедливым представляется мнение о том, что изложенные в постановлениях Пленума Верховного Суда Российской Федерации правовые позиции следует рассматривать в качестве специфических актов судебного толкования ${ }^{29}$. Правовые позиции Верховного Суда Российской Федерации не должны содержать новых элементов правового регулирования в них отражается знание об уже существующих нормативных правовых предписаниях. Примеры определенной «нормативной новизны» правовых позиций Верховного Суда Российской Федерации являются исключением из общего правила ${ }^{30}$. В этой связи под правовой позицией Верховного Суда Российской Федерации следует понимать выраженную в постановлениях Верховного Суда Российской Федерации по конкретным делам и разъяснениях судебной практики систему суждений, содержащих представление

27 Барак А. Судебное усмотрение. М., 1999. С. 13.

28 Власенко Л. В. Налоговые правовые позиции судов: теория и практика. М., 2011. С. 25.

29 Ершова Е. А. Правовая природа постановлений Пленума Верховного Суда РФ // Российское правосудие. 2008. № 11. С. 29.

30 Давид Р., Жоффре-Спинози К. Основные правовые системы современности. М., 1999. С. 98. 
высшего суда общей юрисдикции о понимании и применении правовых норм в процессе осуществления правосудия по гражданским, уголовным и административным делам.

В пункте 4 Постановления Пленума Верховного Суда Российской Федерации от 19 декабря 2003 года № 23 «0 судебном решении» установлено, что суду следует учитывать постановления Пленума Верховного Суда Российской Федерации, принятые на основании статьи 126 Конституции Российской Федерации и содержащие разъяснения вопросов, возникших в судебной практике при применении норм материального или процессуального права, подлежащих применению в данном деле31. Среди ученых и практиков высказываются предложения о предоставлении судам общей юрисдикции права ссылаться на разъяснения Верховного Суда Российской Федерации в судебных актах по конкретным делам32. До настоящего времени этот вопрос на законодательном уровне не разрешен. Как представляется, право суда общей юрисдикции ссылаться на соответствующий акт Верховного Суда Российской Федерации позволит более полно аргументировать выводы решения и обосновать их правильность.
При вынесении какого-либо акта суд руководствуется действующим правом, а позиция Верховного Суда Российской Федерации представляет собой интерпретацию или конкретизацию содержания применяемых судом нормативных предписаний.

В соответствии с этим нельзя признать корректными используемые в судах формулировки: «в соответствии с Постановлением Пленума Верховного Суда Российской Федерации» или «согласно пункту ... Обзора судебной практики» и т.п. Учитывая природу судебной правовой позиции, более правильной представляется формулировка: «по смыслу соответствующих норм закона, что отражено в соответствующем разъяснении практики Верховного Суда Российской Федерации», «согласно ... статье, с учетом разъяснений ...» и другие. Самостоятельная ссылка в судебном постановлении на правовую позицию Верховного Суда Российской Федерации в отрыве от соответствующих нормативных предписаний свидетельствует о неверном представлении правоприменителя о данном феномене. Правовые позиции Верховного Суда Российской Федерации не могут подменять действующие правовые нормы, а служат дополнительным источником обоснования выводов суда.

\section{Библиография}

1. Аверин А. В. Правоприменительная деятельность суда и формирование научно-правового сознания судей: Проблемы теории и практики / под ред. М. И. Байтина. - Саратов: ГОУ ВПО Саратовская государственная академия права, 2003. - с. 308.

2. Алексеев С. С. Право: азбука - теория - философия: Опыт комплексного исследования. - М.: Статут, 1999. - 712 с.

3. Барак А. Судебное усмотрение / Пер. с англ. - М.: Норма, 1999. - 376 с.

4. Барановский К. В., Безруков А. В., Калугин А. Г. Влияние правовых позиций Конституционного Суда РФ на уголовно-процессуальное законодательство и практику //Журнал российского права, 2007. - № 11. - С. 56-68.

5. Бочаров Д. А. О субъектах правых позиций и специфике их правосубъектности // Проблемы правосубъектности: современные интерпретации. Материалы международной науч.-практ. конференции 25 февраля 2011 года, г. Самара / Отв. ред. Т. Б. Замотаева и др. Самара, 2011. С. 115-121.

6. Бурков А. Л. Акты правосудия как источники административного права: Автореф. дисс. ... канд. юридич. наук. - Екатеринбург, 2002. -19 с.

7. Васьковский Е. В. Цивилистическая методология. Учение о толковании и применении гражданских законов. - М.: АО «Центр ЮрИнфоР», 2002. - 508 с.

8. Власенко Н. А., Гринева А. В. Судебные правовые позиции (основы теории). - М.: ИзиСП, ИД «Юриспруденция», 2009. - 168 с.

31 Постановление Пленума Верховного Суда Российской Федерации от 19 декабря 2003 года № 23 «О судебном решении» // Бюллетень Верховного Суда РФ. 2004. № 2. C. 2.

32 Гук П. Судебная практика Верховного Суда РФ: актуальность применения // Арбитражный и гражданский процесс. С. 6; Лебедев В.М. Судебная власть в современной России: проблемы становления и развития. 
9. Власенко Н. А. «Тревожные» вопросы по поводу судебных правовых позиций // Новая юстиция, 2008. - № 1. - С. 24-28.

10. Власенко Л. В. Налоговые правовые позиции судов: теория и практика. М., 2011. - 160 с.

11. Витрук Н. В. Новое в конституционном судопроизводстве (к вступлению в силу федерального конституционного закона от 3 ноября 2010 года) // Российское правосудие. 2011. № 3. С. 4-13.

12. Витрук Н. В. О некоторых особенностях использования решений Европейского Суда по правам человека в практике Конституционного Суда РФ и иных судов // Антология научной мысли: К 10-летию Российской академии правосудия: Сб. ст. / кол. авт. - М.: Статут, 2008. - С. 545-553.

13. Гаджиев Г. А. Правовые позиции Конституционного Суда РФ как новый источник российского гражданского права // Закон, 2006. - № 11. - С. 22-32.

14. Груздев В. В. Проблемы судебного толкования права в России // Российский судья, 2008. - № 5.- С. 36-39.

15. Гук П. Судебная практика Верховного Суда РФ: актуальность применения // Арбитражный и гражданский процесс, 2004. - № 2. - С. 22-26.

16. Гусева Т. А. Значение судебных актов Конституционного Суда РФ // Ваш налоговый адвокат, 2008. - № 5. - С. 18-25.

17. Гринева А. В. Судебные правовые позиции: вопросы теории: Автореф. дисс... канд. юридич. наук. - М., 2008. - 25 с.

18. Давид Р., Жоффре-Спинози К. Основные правовые системы современности / Пер с франц. В. А. Туманова. - М.: Междунар. отношения, 1999. - 400 с.

19. Дихтяр А. И., Рогожин Н. А. Источники права и судебная практика // Юрист, 2003. - №1. - С. 2-7.

20. Ершов В. В., Ершова Е. А. О правовом статусе Конституционного Суда Российской Федерации // Российский судья, 2004. -№ 3. - С. 8-13.

21. Ершов В. В. Правовая природа правовых позиций суда // Российское правосудие, 2013, № 6. - C. $37-47$.

22. Ершова Е. А. Юридическая природа правовых позиций Конституционного Суда // Российский судья, 2005. - № 2. - С. 9-15.

23. Ершова Е. А. Правовая природа постановлений Пленума Верховного Суда РФ // Российское правосудие, 2008. - № 11. - С. 29-39.

24. Зорькин В. Д. Прецедентный характер решений Конституционного Суда РФ // Журнал российского права, 2004. - № 12. - С. 3-9.

25. Красюков А. В. Правовые позиции Высшего Арбитражного Суда РФ и налоговое обязательство // Российское правосудие. 2011. № 9. С. 77-84.

26. Кряжкова О. Н. Правовые позиции Конституционного Суда РФ: теоретические основы и практика реализации судами России. - М.: Формула Права, 2006. - 152 с.

27. Лазарев Л. В. Правовые позиции Конституционного Суда РФ. - М.: Формула права, 2008. - 688 с.

28. Лебедев В. М. Судебная власть в современной России: проблемы становления и развития. СПб.: Лань, 2001. - 384 с.

29. Марченко М. Н. Судебное правотворчество и судейское право. - М.: Проспект, 2008. -512 с.

30. Нерсесянц В. С. Теория государства и права. - М.: Норма, 2001. - 272 с.

31. Ножкина А. В. Система источников уголовно-процессуального права России : Дисс. ... канд. юрид. наук. - М., 2003. - 190 с.

32. Основы судебной власти и правосудия в РФ: Курс лекций / под ред. В. И. Анишиной. - М.: Эксмо, 2008. - 272 с.

33. Самостоятельность и независимость судебной власти в Российской Федерации / Под ред. В. В. Ершова. - М.: Юристъ, 2006. - 493 с.

34. Смирнов А. В., Манукян А. Г. Толкование норм права: учебно-практич. пособие. - М.: Проспект, 2008. - 144 с.

35. Спектор Е. И. Судебный прецедент как источник права // Журнал Российского права, 2003. № 5. - С. 86-96.

36. Теория права и государства. Учебник / Под ред. В. В. Лазарева - М.: Право и закон, 2002. - 576 с.

37. Туманова Л. В. Проблемы обеспечения права на независимый и беспристрастный суд // Концепция развития судебной системы и системы добровольного и принудительного исполнения решений Конституционного Суда РФ, судов общей юрисдикции, арбитражных, третейских судов и Европейского Суда по правам человека: Сб. науч. ст. / отв. ред. Г. Д. Улетова-Краснодар - СПб.: Изд-во Р. Асланова «Юридический центр Пресс», 2007. - С. 27-34.

38. Фархтдинов Я. В. Источники гражданского процессуального права Российской Федерации: 
дисс... д-ра юрид. наук. - Екатеринбург, 2002. - 375 с.

39. Цихоцкий А. В. Аналогия права в механизме судебного правоприменения // Концепция развития судебной системы и системы добровольного и принудительного исполнения решений Конституционного Суда РФ, судов общей юрисдикции, арбитражных, третейских судов и Европейского суда по правам человека: Сб. науч. ст. / отв. ред. Г. Д. Улетова-Краснодар СПб.: Изд-во Р. Асланова «Юридический центр Пресс», 2007. - С. 224-232.

40. Черданцев А. Ф. Толкование советского права. М.: Юридическая литература, 1979. - 168 с.

\section{References}

1. Averin A. V. Pravoprimenitel'naya deyatel'nost' suda i formirovanie nauchno-pravovogo soznaniya sudei: Problemy teorii i praktiki / pod red. M. I. Baitina. - Saratov: GOU VPO Saratovskaya gosudarstvennaya akademiya prava, 2003. - s. 308.

2. Alekseev S. S. Pravo: azbuka - teoriya - filosofiya: Opyt kompleksnogo issledovaniya. - M.: Statut, 1999. $-712 \mathrm{~s}$.

3. Barak A. Sudebnoe usmotrenie / Per. s angl. - M.: Norma, 1999. - 376 s.

4. Baranovskii K. V., Bezrukov A. V., Kalugin A. G. Vliyanie pravovykh pozitsii Konstitutsionnogo Suda RF na ugolovno-protsessual'noe zakonodatel'stvo i praktiku //Zhurnal rossiiskogo prava, 2007. № 11. - S. 56-68.

5. Bocharov D. A. O sub"ektakh pravykh pozitsii i spetsifike ikh pravosub"ektnosti // Problemy pravosub"ektnosti: sovremennye interpretatsii. Materialy mezhdunarodnoi nauch.-prakt. konferentsii 25 fevralya 2011 goda, g. Samara / Otv. red. T. B. Zamotaeva i dr. Samara, 2011. S. 115-121.

6. Burkov A. L. Akty pravosudiya kak istochniki administrativnogo prava: Avtoref. diss. ... kand. yuridich. nauk. - Ekaterinburg, 2002. -19 s.

7. Vas'kovskii E. V. Tsivilisticheskaya metodologiya. Uchenie o tolkovanii i primenenii grazhdanskikh zakonov. - M.: AO «Tsentr YurInfoR», 2002. - 508 s.

8. Vlasenko N. A., Grineva A. V. Sudebnye pravovye pozitsii (osnovy teorii). - M.: IziSP, ID «Yurisprudentsiya», 2009. - $168 \mathrm{~s}$.

9. Vlasenko N. A. «Trevozhnye» voprosy po povodu sudebnykh pravovykh pozitsii // Novaya yustitsiya, 2008. - № 1. - S. 24-28.

10. Vlasenko L. V. Nalogovye pravovye pozitsii sudov: teoriya i praktika. M., 2011. - $160 \mathrm{~s}$.

11. Vitruk N. V. Novoe $\mathrm{v}$ konstitutsionnom sudoproizvodstve (k vstupleniyu $\mathrm{v}$ silu federal'nogo konstitutsionnogo zakona ot 3 noyabrya 2010 goda) // Rossiiskoe pravosudie. 2011. № 3. S. 4-13.

12. Vitruk N. V. O nekotorykh osobennostyakh ispol'zovaniya reshenii Evropeiskogo Suda po pravam cheloveka v praktike Konstitutsionnogo Suda RF i inykh sudov // Antologiya nauchnoi mysli: K 10-letiyu Rossiiskoi akademii pravosudiya: Sb. st. / kol. avt. - M.: Statut, 2008. - S. 545-553.

13. Gadzhiev G. A. Pravovye pozitsii Konstitutsionnogo Suda RF kak novyi istochnik rossiiskogo grazhdanskogo prava // Zakon, 2006. - № 11. - S. 22-32.

14. Gruzdev V. V. Problemy sudebnogo tolkovaniya prava v Rossii // Rossiiskii sud'ya, 2008. - № 5.- S. 36-39.

15. Guk P. Sudebnaya praktika Verkhovnogo Suda RF: aktual'nost' primeneniya // Arbitrazhnyi i grazhdanskii protsess, 2004. - № 2. - S. 22-26.

16. Guseva T. A. Znachenie sudebnykh aktov Konstitutsionnogo Suda RF // Vash nalogovyi advokat, 2008. - № 5. - S. 18-25.

17. Grineva A. V. Sudebnye pravovye pozitsii: voprosy teorii: Avtoref. diss... kand. yuridich. nauk. - M., 2008. - 25 s.

18. David R., Zhoffre-Spinozi K. Osnovnye pravovye sistemy sovremennosti / Pers frants.V.A.Tumanova.M.: Mezhdunar. otnosheniya, 1999. - $400 \mathrm{~s}$.

19. Dikhtyar A. I., Rogozhin N. A. Istochniki prava i sudebnaya praktika // Yurist, 2003. - №1. - S. 2-7.

20. Ershov V. V., Ershova E. A. O pravovom statuse Konstitutsionnogo Suda Rossiiskoi Federatsii // Rossiiskii sud'ya, 2004. -№ 3. - S. 8-13.

21. Ershov V. V. Pravovaya priroda pravovykh pozitsii suda // Rossiiskoe pravosudie, 2013, № 6. S. 37-47.

22. Ershova E. A. Yuridicheskaya priroda pravovykh pozitsii Konstitutsionnogo Suda // Rossiiskii sud'ya, 2005. - № 2. - S. 9-15.

23. Ershova E. A. Pravovaya priroda postanovlenii Plenuma Verkhovnogo Suda RF // Rossiiskoe pravosudie, 2008. - № 11. - S. 29-39.

24. Zor'kin V. D. Pretsedentnyi kharakter reshenii Konstitutsionnogo Suda RF // Zhurnal rossiiskogo prava, 2004. - № 12. - S. 3-9. 
25. Krasyukov A. V. Pravovye pozitsii Vysshego Arbitrazhnogo Suda RF i nalogovoe obyazatel'stvo // Rossiiskoe pravosudie. 2011. № 9. S. 77-84.

26. Kryazhkova O. N. Pravovye pozitsii Konstitutsionnogo Suda RF: teoreticheskie osnovy i praktika realizatsii sudami Rossii. - M.: Formula Prava, 2006. - 152 s.

27. Lazarev L. V. Pravovye pozitsii Konstitutsionnogo Suda RF. - M.: Formula prava, 2008. - 688 s.

28. Lebedev V. M. Sudebnaya vlast' v sovremennoi Rossii: problemy stanovleniya i razvitiya. - SPb.: Lan', 2001. - 384 s.

29. Marchenko M. N. Sudebnoe pravotvorchestvo i sudeiskoe pravo. - M.: Prospekt, 2008. -512 s.

30. Nersesyants V. S. Teoriya gosudarstva i prava. - M.: Norma, 2001. - $272 \mathrm{~s}$.

31. Nozhkina A. V. Sistema istochnikov ugolovno-protsessual'nogo prava Rossii : Diss. ... kand. yurid. nauk. - M., 2003. - $190 \mathrm{~s}$.

32. Osnovy sudebnoi vlasti i pravosudiya v RF: Kurs lektsii / pod red. V. I. Anishinoi. - M.: Eksmo, 2008. -272 s.

33. Samostoyatel'nost' i nezavisimost' sudebnoi vlasti v Rossiiskoi Federatsii / Pod red. V. V. Ershova. M.: Yurist", 2006. - 493 s.

34. Smirnov A. V., Manukyan A. G. Tolkovanie norm prava: uchebno-praktich. posobie. - M.: Prospekt, 2008. - $144 \mathrm{~s}$.

35. Spektor E. I. Sudebnyi pretsedent kak istochnik prava // Zhurnal Rossiiskogo prava, 2003. - № 5. S. 86-96.

36. Teoriya prava i gosudarstva. Uchebnik / Pod red. V. V. Lazareva - M.: Pravo i zakon, 2002. - 576 s.

37. Tumanova L. V. Problemy obespecheniya prava na nezavisimyi i bespristrastnyi sud // Kontseptsiya razvitiya sudebnoi sistemy i sistemy dobrovol'nogo i prinuditel'nogo ispolneniya reshenii Konstitutsionnogo Suda RF, sudov obshchei yurisdiktsii, arbitrazhnykh, treteiskikh sudov i Evropeiskogo suda po pravam cheloveka: Sb. nauch. st. / otv. red. G. D. Uletova-Krasnodar - SPb.: Izd-vo R. Aslanova «Yuridicheskii tsentr Press», 2007. - S. 27-34.

38. Farkhtdinov Ya. V. Istochniki grazhdanskogo protsessual'nogo prava Rossiiskoi Federatsii: diss... d-ra yurid. nauk. - Ekaterinburg, 2002. - 375 s.

39. Tsikhotskii A. V. Analogiya prava v mekhanizme sudebnogo pravoprimeneniya // Kontseptsiya razvitiya sudebnoi sistemy i sistemy dobrovol'nogo i prinuditel'nogo ispolneniya reshenii Konstitutsionnogo Suda RF, sudov obshchei yurisdiktsii, arbitrazhnykh, treteiskikh sudov i Evropeiskogo suda po pravam cheloveka: Sb. nauch. st. / otv. red. G. D. Uletova-Krasnodar - SPb.: Izd-vo R. Aslanova «Yuridicheskii tsentr Press», 2007. - S. 224-232.

40. Cherdantsev A. F. Tolkovanie sovetskogo prava. M.: Yuridicheskaya literatura, 1979. - $168 \mathrm{~s}$.

Материал поступил в редакцию 04 декабря 2013 г. 